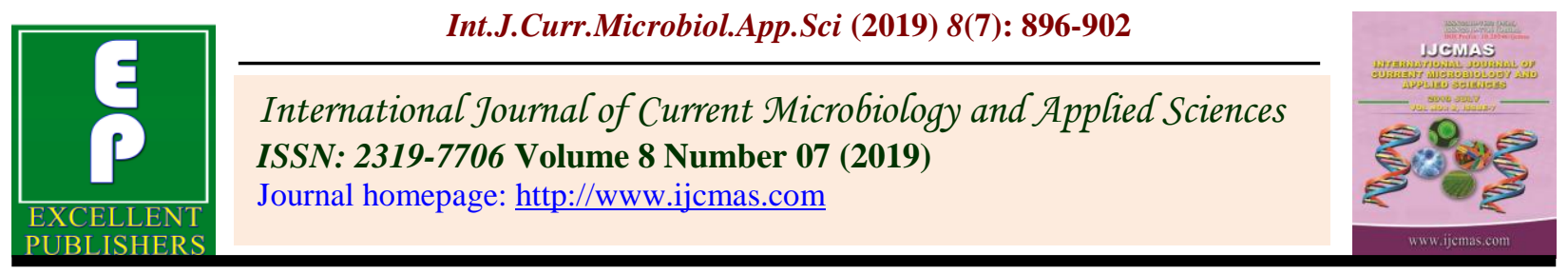

\title{
Effect of Site Specific Nutrient Management, Crop Establishment Methods and Date of Sowing on Growth, Yield and Economics of Bt Cotton
}

\author{
P.S. Pyati ${ }^{*}$, B.M. Chittapur ${ }^{2}$, A.S. Halepyati ${ }^{2}$, U.K. Shanwad ${ }^{2}$ and S.N. Bhat ${ }^{2}$ \\ ${ }^{1}$ ICAR-National Dairy Research Institute, Karnal-132001, Haryana, India \\ ${ }^{2}$ University of Agricultural Sciences, Raichur- 584104, Karnataka, India \\ *Corresponding author
}

\section{A B S T R A C T}

A field experiment was conducted at Agronomy Farm, University of Agricultural Sciences, Raichur in 2015-16 on effect of site specific nutrient management, crop establishment methods and date of sowing on growth, yield and economics of $B t$

Keywords

Seed cotton,

Economics,

Transplanting, Date

of sowing

Article Info

Accepted:

10 June 2019

Available Online:

10 July 2019 cotton. The experiment was laid out in Split Plot Design (SPD) with three replications. Two methods of crop establishment as main factor viz. $\mathrm{M}_{1}$ : Dibbling method and $\mathrm{M}_{2}$ : Transplanting method and five dates of sowing as sub factor viz. $D_{1}: 1^{\text {st }}$ fortnight of June, $D_{2}: 2^{\text {nd }}$ fortnight of June, $D_{3}: 1^{\text {st }}$ fortnight of July, $D_{4}: 2^{\text {nd }}$ fortnight of July and $\mathrm{D}_{1}: 1^{\text {st }}$ fortnight of August. Fertilizer doses were applied according SSNM recommendation. Significantly higher seed cotton yield (4426 $\mathrm{kg} \mathrm{ha}^{-1}$ ), seed cotton yield per plant $(272.67 \mathrm{~g}$ ), total dry matter production (525 g per plant) recorded in treatment transplanted on $1^{\text {st }}$ fortnight of June over dibbling method and later dates of sowing. However, there was no significant difference observed with respect to net returns and B: C ratio. Higher net returns (Rs. 141616 $\mathrm{ha}^{-1}$ ) and B: C (3.93) ratio recorded in treatment transplanted on $1^{\text {st }}$ fortnight of June over dibbling method and later dates of sowing. Transplanting $B t$ cotton on $1^{\text {st }}$ fortnight of June recorded higher seed cotton yield, total dry matter, net returns and $\mathrm{B}$ : C ratio.

\section{Introduction}

Karnataka, in India ranks fifth in area, fourth in production and fifth in productivity among the cotton growing states. $B t$ cotton is intensively cultivated in the North Eastern Dry Zone and Northern Dry Zone of the state (Zone 2 and 3) covering partly the Tungabhadra and Upper Krishna (TBP and UKP) irrigation Commands on black soil. The area under this crop in these commands has been increasing distinctly over the past half a decade. The average yields which hovered around 4.0 to $5.0 \mathrm{t} \mathrm{ha}^{-1}$ initially with the advent of $B t$ cultivars of late are either remaining stagnant of declining which is a deterrent to the farmers due to squeezing returns and hence needs special attention. In the Northern Karnataka region, there are several reasons for the low yields in cotton 
such as imbalanced fertilizers application, late planting and improper pest management etc. where the rainy season starts probably during second fortnight of June to as late as August.

Therefore, there is very large yield gap between the average productivity of the country and of the region under the study. In this context, there is need for efforts to achieve pre-set yield targets with balanced fertilization and appropriate method of planting. Transplanting, which was found promising in cotton in UKP irrigation project (Salakinkop, 2011 and Honnali and Chittapur, 2013) was hypothesized to make good yield losses caused due to late planting as a month old seedlings are used for planting and these seedlings could pick up their growth from where they have stopped in the nursery.

Profitability of using transplanting or dibbling and SSNM practice to improve the efficiency of $B t$ cotton production with enhanced B: C ratio. Hence, the present study on impact of method of establishment and time of planting on seed cotton yield and its economics was envisaged in the Tunga Bhadra irrigation command on vertisols.

\section{Materials and Methods}

The experiment was conducted at Agronomy farm, University of Agricultural Sciences, Raichur during kharif season of 2015-16. The soil was medium deep black clay having $\mathrm{pH}$ 8.2 and electrical conductivity (EC) of $0.24 \mathrm{dS}$ $\mathrm{m}^{-1}$. The soil had medium organic carbon $(0.62 \%)$, low available nitrogen $\left(220 \mathrm{~kg} \mathrm{ha}^{-1}\right)$, high available phosphorus (31 kg ha-1) and high available potassium $\left(283.45 \mathrm{~kg} \mathrm{ha}^{-1}\right)$. The experiment was laid out in Split Plot Design with three replications. First factor consisted two methods of establishment $\mathrm{M}_{1}$ : Dibbling method and $\mathrm{M}_{2}$ : Transplanting method and second factor consisted five dates of sowing as sub factor viz. $\mathrm{D}_{1}: 1^{\text {st }}$ fortnight of June, $\mathrm{D}_{2}: 2^{\text {nd }}$ fortnight of June, $\mathrm{D}_{3}: 1^{\text {st }}$ fortnight of July, $\mathrm{D}_{4}$ : $2^{\text {nd }}$ fortnight of July and $D_{1}: 1^{\text {st }}$ fortnight of August. Amount of fertilizer applied was calculated based on SSNM recommended by IPNI and the fertilizer was applied in two splits viz. first split at the time of sowing and second split was applied at 60 DAS. The crop was sown according to the treatment i.e, five dates of sowing at the interval of fifteen days from $1^{\text {st }}$ fortnight of June to $1^{\text {st }}$ fortnight of August. Sowing of seeds was done by dibbling method for dibbling treatments and for treatments with transplanting, 25 days old seedlings were transplanted. For transplanting, 25 days before, the seeds were sown in poly bags in the nursery and timely irrigation and other management practices were done.

The spacing maintained for both dibbling and transplanting of cotton was $90 \times 60 \mathrm{~cm}$. gross plot size $7.2 \times 6.0 \mathrm{~m}$ and net plot size $5.6 \times 4.2$ $\mathrm{m}$. five plants were tagged randomly in net plots for recording growth and yield attributes of crop different treatments. Yield and yield parameters were recorded periodically till harvest during both the years. Economics of the cotton cultivation was analyzed by using cost of cultivation, gross returns and net returns. B: $\mathrm{C}$ ratio was calculated by diving gross returns by cost of cultivation. The data collected from the experiment were subjected to statistical analysis as described by Gomez and Gomez (1984).

\section{Results and Discussion}

The total dry matter (TDM) production increased with advancement in crop age towards maturity and varied significantly due to crop establishment and varied dates of planting. At harvest, TDM recorded significantly higher with transplanting (505.20 g/plant) compared with dibbling method (491.45 g/plant). TDM was significantly influenced by varied dates of planting at all the growth stages (Fig. 1 and 2). 
Table.1 Dry matter production, boll weight, seed cotton yield in $B t$ cotton as influenced by planting technique and time of planting

\begin{tabular}{|c|c|c|c|c|c|}
\hline Treatments & $\begin{array}{l}\text { Dry matter } \\
\text { production } \\
\text { (g/plant) }\end{array}$ & $\begin{array}{c}\text { Boll } \\
\text { weight } \\
\text { (g) }\end{array}$ & $\begin{array}{c}\text { Number } \\
\text { of bolls } \\
\text { per plant }\end{array}$ & $\begin{array}{c}\text { Seed cotton } \\
\text { yield } \\
\text { (g/plant) }\end{array}$ & $\begin{array}{c}\text { Seed cotton } \\
\text { yield } \\
(\mathrm{kg} / \mathrm{ha})\end{array}$ \\
\hline \multicolumn{6}{|l|}{ Crop establishment (M) } \\
\hline $\begin{array}{l}\mathbf{M}_{1}: \text { Dibbling } \\
\mathbf{M}_{2}: \text { Transplanting }\end{array}$ & $\begin{array}{l}491.45 \\
505.02\end{array}$ & $\begin{array}{l}4.62 \\
5.09\end{array}$ & $\begin{array}{l}42.72 \\
45.97\end{array}$ & $\begin{array}{l}178.40 \\
205.11\end{array}$ & $\begin{array}{l}3280 \\
3457\end{array}$ \\
\hline $\begin{array}{c}\text { S. Em. } \pm \\
\text { C. D. at } 5 \%\end{array}$ & $\begin{array}{l}0.95 \\
6.24\end{array}$ & $\begin{array}{l}0.07 \\
0.42\end{array}$ & $\begin{array}{l}0.28 \\
1.82\end{array}$ & $\begin{array}{c}2.54 \\
16.63\end{array}$ & $\begin{array}{c}19.60 \\
128.41\end{array}$ \\
\hline \multicolumn{6}{|l|}{ Date of planting (D) } \\
\hline $\begin{array}{l}D_{1}: 1^{\text {st }} \text { fortnight of June } \\
D_{2}: 2^{\text {nd }} \text { fortnight of } \\
\text { June } \\
D_{3}: 1^{\text {st }} \text { fortnight of July } \\
D_{4}: 2^{\text {nd }} \text { fortnight of July } \\
D_{5}: 1^{\text {st }} \text { fortnight of } \\
\text { August }\end{array}$ & $\begin{array}{c}522.76 \\
515.69 \\
504.16 \\
484.12 \\
464.45\end{array}$ & $\begin{array}{l}5.45 \\
5.14 \\
4.80 \\
4.50 \\
4.38\end{array}$ & $\begin{array}{l}52.43 \\
52.07 \\
45.50 \\
39.37 \\
32.37\end{array}$ & $\begin{array}{l}255.50 \\
232.28 \\
210.50 \\
158.33 \\
102.17\end{array}$ & $\begin{array}{l}4,401 \\
4,277 \\
3,698 \\
2,693 \\
1,773\end{array}$ \\
\hline $\begin{array}{c}\text { S. Em. } \pm \\
\text { C. D. at } 5 \%\end{array}$ & $\begin{array}{l}1.34 \\
4.06\end{array}$ & $\begin{array}{l}0.08 \\
0.24\end{array}$ & $\begin{array}{l}0.66 \\
1.99\end{array}$ & $\begin{array}{c}3.99 \\
12.07\end{array}$ & $\begin{array}{c}41 \\
124\end{array}$ \\
\hline \multicolumn{6}{|l|}{ Interaction effect of $M \times D$} \\
\hline $\begin{array}{l}\mathbf{M}_{1} \mathbf{D}_{1} \\
\mathbf{M}_{1} \mathbf{D}_{2} \\
\mathbf{M}_{1} \mathbf{D}_{3} \\
\mathbf{M}_{1} \mathbf{D}_{4} \\
\mathbf{M}_{1} \mathbf{D}_{5} \\
\mathbf{M}_{2} \mathbf{D}_{1} \\
\mathbf{M}_{2} \mathbf{D}_{2} \\
\mathbf{M}_{2} \mathbf{D}_{3} \\
\mathbf{M}_{2} \mathbf{D}_{4} \\
\mathbf{M}_{2} \mathbf{D}_{5}\end{array}$ & $\begin{array}{l}520.00 \\
511.09 \\
497.03 \\
470.85 \\
458.29 \\
525.52 \\
520.30 \\
511.29 \\
497.39 \\
470.62\end{array}$ & $\begin{array}{l}5.19 \\
5.00 \\
4.59 \\
4.24 \\
4.07 \\
5.71 \\
5.28 \\
5.01 \\
4.76 \\
4.70\end{array}$ & $\begin{array}{l}49.20 \\
49.87 \\
44.47 \\
38.53 \\
31.53 \\
55.67 \\
54.27 \\
46.53 \\
40.20 \\
33.20\end{array}$ & $\begin{array}{c}238.33 \\
220.67 \\
199.33 \\
146.00 \\
87.67 \\
272.67 \\
243.90 \\
221.67 \\
170.67 \\
116.67\end{array}$ & $\begin{array}{l}4,376 \\
4,198 \\
3,576 \\
2,609 \\
1,640 \\
4,426 \\
4,356 \\
3,819 \\
2,777 \\
1,906\end{array}$ \\
\hline $\begin{array}{c}\text { S. Em. } \pm \\
\text { C. D. at } 5 \%\end{array}$ & $\begin{array}{l}1.95 \\
7.52\end{array}$ & $\begin{array}{l}0.12 \\
\text { NS }\end{array}$ & $\begin{array}{l}0.88 \\
\text { NS }\end{array}$ & $\begin{array}{l}5.05 \\
\text { NS }\end{array}$ & $\begin{array}{l}55 \\
\text { NS }\end{array}$ \\
\hline
\end{tabular}

NS: Non significant 
Table. 2 Economics of $B t$ cotton cultivation as influenced by planting technique and Time of planting

\begin{tabular}{|c|c|c|c|c|}
\hline Treatment & $\begin{array}{c}\text { Cost of } \\
\text { Cultivation } \\
\left(\operatorname{Rs~ha}^{-1}\right)\end{array}$ & $\begin{array}{l}\text { Gross returns } \\
\left(\mathrm{Rs} \mathrm{ha}^{-1}\right)\end{array}$ & $\begin{array}{c}\text { Net } \\
\text { returns } \\
\left(\mathrm{Rs} \mathrm{ha}^{-1}\right)\end{array}$ & $\begin{array}{l}\text { Benefit : cost } \\
\text { ratio }\end{array}$ \\
\hline \multicolumn{5}{|l|}{ Crop establishment (M) } \\
\hline $\begin{array}{l}M_{1}: \text { Dibbling } \\
M_{2}: \text { Transplanting }\end{array}$ & $\begin{array}{l}48257 \\
49256\end{array}$ & $\begin{array}{l}141037 \\
148639\end{array}$ & $\begin{array}{l}92780 \\
99383\end{array}$ & $\begin{array}{l}2.92 \\
3.01\end{array}$ \\
\hline $\begin{array}{c}\text { S. Em. } \pm \\
\text { C.D. at } 5 \%\end{array}$ & $\begin{array}{c}279 \\
1953\end{array}$ & $\begin{array}{c}842 \\
5521\end{array}$ & $\begin{array}{c}842 \\
5521\end{array}$ & $\begin{array}{l}0.06 \\
0.01\end{array}$ \\
\hline \multicolumn{5}{|l|}{ Time of planting (D) } \\
\hline $\begin{array}{l}D_{1}: 1^{\text {st }} \text { fortnight of June } \\
D_{2}: 2^{\text {nd }} \text { fortnight of June } \\
D_{3}: 1^{\text {st }} \text { fortnight of July } \\
D_{4}: 2^{\text {nd }} \text { fortnight of July } \\
D_{5}: 1^{\text {st }} \text { fortnight of August }\end{array}$ & $\begin{array}{l}48187 \\
49331 \\
48867 \\
48830 \\
48570\end{array}$ & $\begin{array}{l}189229 \\
183918 \\
159000 \\
115799 \\
76248\end{array}$ & $\begin{array}{c}141042 \\
134587 \\
110133 \\
66969 \\
27678\end{array}$ & $\begin{array}{l}3.93 \\
3.72 \\
3.23 \\
2.38 \\
1.57\end{array}$ \\
\hline $\begin{array}{c}\text { S. Em. } \pm \\
\text { C.D. at } 5 \%\end{array}$ & $\begin{array}{l}1264 \\
1862\end{array}$ & $\begin{array}{l}1843 \\
5573\end{array}$ & $\begin{array}{l}1843 \\
5573\end{array}$ & $\begin{array}{l}0.13 \\
0.04\end{array}$ \\
\hline \multicolumn{5}{|l|}{ Interaction effect of M x D } \\
\hline $\begin{array}{l}M_{1} D_{1} \\
M_{1} D_{2} \\
M_{1} D_{3} \\
M_{1} D_{4} \\
M_{1} D_{5} \\
M_{2} D_{1} \\
M_{2} D_{2} \\
M_{2} D_{3} \\
M_{2} D_{4} \\
M_{2} D_{5}\end{array}$ & $\begin{array}{l}47687 \\
48831 \\
48366 \\
48330 \\
48068 \\
48687 \\
49831 \\
49366 \\
49330 \\
49068\end{array}$ & $\begin{array}{c}188153 \\
180514 \\
153782 \\
112201 \\
70534 \\
190303 \\
187322 \\
164217 \\
119396 \\
81958\end{array}$ & $\begin{array}{c}140466 \\
131683 \\
105416 \\
63871 \\
22466 \\
141616 \\
137491 \\
114850 \\
70067 \\
32890\end{array}$ & $\begin{array}{l}3.93 \\
3.70 \\
3.17 \\
2.33 \\
1.47 \\
3.93 \\
3.73 \\
3.30 \\
2.43 \\
1.67\end{array}$ \\
\hline $\begin{array}{l}\text { S. Em. } \pm \\
\text { C.D. at } 5 \%\end{array}$ & $\begin{array}{l}1285 \\
\text { NS }\end{array}$ & $\begin{array}{l}1855 \\
\text { NS }\end{array}$ & $\begin{array}{c}1885 \\
\text { NS }\end{array}$ & $\begin{array}{l}0.02 \\
\text { NS }\end{array}$ \\
\hline
\end{tabular}

NS: Non significant 
Fig.1 Yield response curve of $B t$ cotton under different methods of establishment and dates of planting as influenced by dry matter production

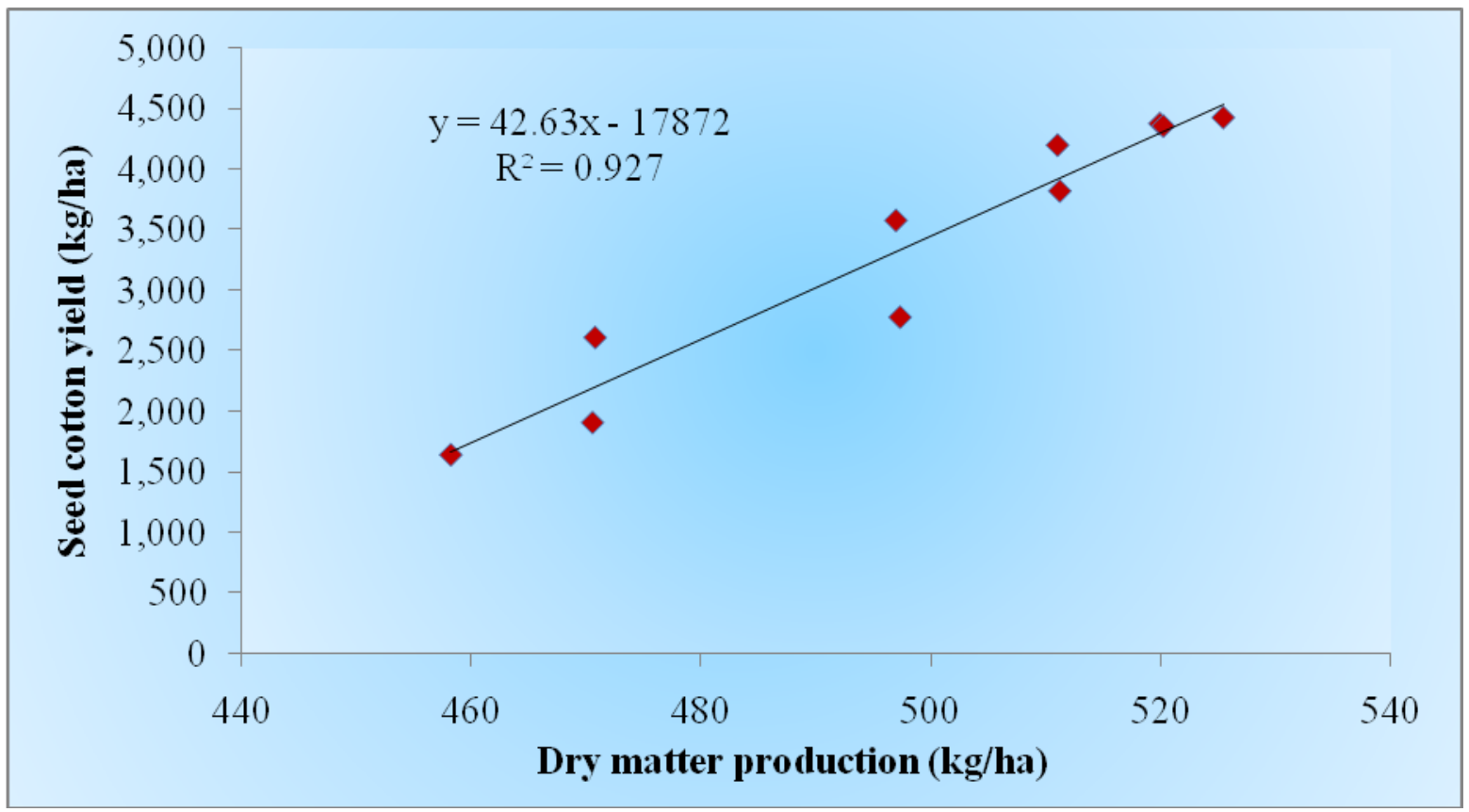

Fig.2 Net returns response curve of $B t$ cotton under different methods of establishment and dates of planting as influenced by seed cotton yield

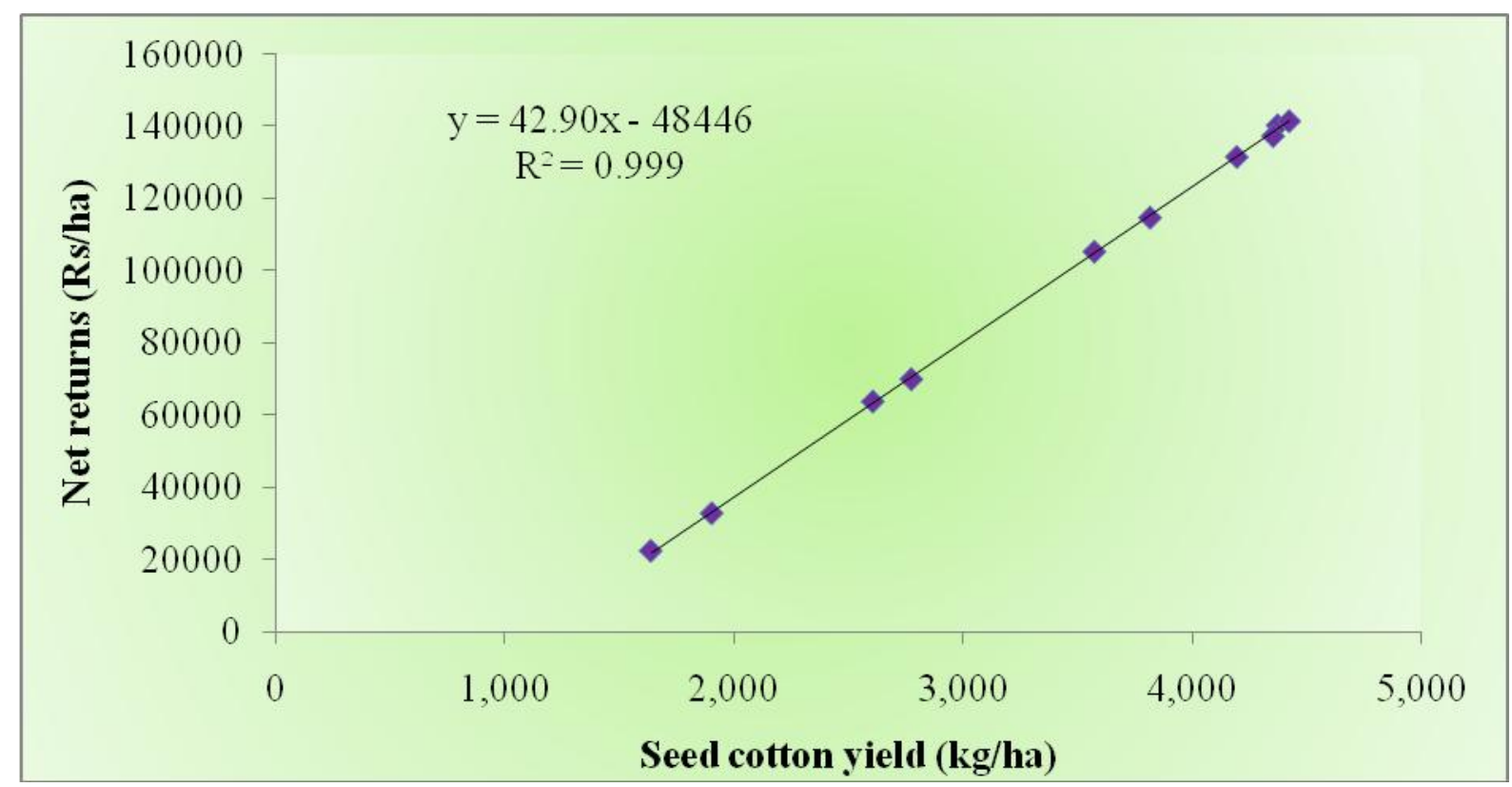

At harvest, significantly higher TDM was recorded with $1^{\text {st }}$ fortnight of June planted crop (522.76 g palnt $^{-1}$, respectively) compared to all other times of planting. The interaction effect of crop establishment and time of planting was not significant with respect to TDM at all growth stages except at harvest, wherein it was significantly higher with 
transplanting on $1^{\text {st }}$ fortnight of June (525.52 $\mathrm{g} / \mathrm{plant}$ ) compared to other treatment combinations and was on par with transplanting on $2^{\text {nd }}$ fortnight of June (520.30 $\mathrm{g} /$ plant) and dibbling on $1^{\text {st }}$ fortnight of June (520.00 g/plant). Lower TDM was recorded with $1^{\text {st }}$ fortnight of August with transplanting (470.62 g/plant) and dibbling as well (458.29 g/plant) (Table 1). Elayan et al., (2015) opined that delayed planting pushes cotton plant for an early flowering and maturity. With insufficient availability of photosynthates boll development, boll weight, good opened bolls per plant and number of bolls per plant get reduced resulting in lower kapas yield under delayed planting. Haung et al., (2015) attributed lower yields under late planting to less above ground dry matter as evidenced in the present study.

The maximum average yield achieved was $3457 \mathrm{~kg}$ per ha with transplanting averaged over all planting times while with time of planting average over methods of establishment was $4401 \mathrm{~kg}$ per ha. Nevertheless, transplanting during $1^{\text {st }}$ fortnight of June produced $4426 \mathrm{~kg}$ per ha while dibbling during same period produce $4376 \mathrm{~kg}$ per ha and the yield exceeded 4 tonnes per ha with both the methods when planted during June. However, yield decreased substantially with every subsequent fortnight delay in planting and was less than half the best yields when planting was done during the $1^{\text {st }}$ fortnight of August.

Thus, it was clear that delayed planting would lead to yield reduction in spite of applying major nutrients for higher yields $\left(5 \mathrm{tha}^{-1}\right)$ and planting methods would not help in recovering the yield losses though transplanting marginally fared better than dibbling. The increase in yield with transplanting over dibbling was 32 per cent. Results are in line with Honnali and Chittapur (2013). Higher kapas yields with early planting (June planting) irrespective of method of planting could be attributed to seed cotton yield per plant (272.67 and $238.33 \mathrm{~g}$ ), boll weight (5.71 and $5.19 \mathrm{~g} / \mathrm{boll})$, respectively with transplanting and dibbling during $1^{\text {st }}$ fort night of June). In other words, more bolls were retained with early planting than with late planting though the data at 90 DAS is quite reverse which is acceptable because of extreme stress on source sink relation due to peak vegetative growth as well as initiation of reproductive growth and hence, this impact could be ignored. The results are in line with Iqbal et al., (2012), Zaheer et al., (2014) and Rajesh Kumar et al., (2014). Elayan et al., (2015) reported a yield increase of 29 per cent with early planting $\left(3^{\text {rd }}\right.$ week of May) over delayed planting $\left(2^{\text {nd }}\right.$ week of June) (Table 1).

As a consequence of higher yield and better quality kapas obtained with early planting in June returns of cotton production were far superior over crops sown late beyond June. Gross returns (Rs. 190303 ha $^{-1}$ and 188153 $\mathrm{ha}^{-1}$, respectively with transplanting and dibbling), net returns (Rs. $141616 \mathrm{ha}^{-1}$ and $140466 \mathrm{ha}^{-1}$, respectively with transplanting and dibbling) and also benefit cost ratio (3.93 and 3.93, respectively with transplanting and dibbling) were higher with June planted crop than with crops sown late in July or early part of August (Table 2). Thus, crop productivity and economic returns were superior in cotton sown early during the season with kapas yield exceeding $4 \mathrm{t} \mathrm{ha}{ }^{-1}$. Transplanting technique may be advantageously used if facilities are available and a week or two delays in planting could be taken care of.

The study revealed advantage of early planting in June, transplanting and site specific nutrient management to realize higher dry matter production, seed cotton yield, net returns and $\mathrm{B}: \mathrm{C}$ ratio. 


\section{References}

Elayan E. D., Sohair, Abdalla, A. M. A., Abdel Gawad. 2015. Effect of delaying planting date on yield, fiber and yarn quality properties in some cultivars and promising crosses of Egyptian cotton. American-Eurasian Journal Agriculture and Environmental Sciences, 15 (5): 754-763.

Gomez, K. A. and Gomez, A. A. 1984. Statistical Procedures for Agricultural Research, $2^{\text {nd }}$ Edition, A WileyInternational Science Publication, New York (USA), pp. 125-130.

Haung, J., 2015, Effects of meteorological parameters created by different planting dates on drip irrigated cotton yield and yield components in arid regions in China Journal of Horticulture 2:4-8.

Honnali, S. N. and Chittapur, B. M. 2013. Enhancing Bt Cotton (Gossypium spp.) productivity through transplanting in
Upper Krishna Project (UKP) command area of Karnataka. Indian Journal Agronomy, 58 (1):105-108.

Iqbal, J., Wajid, S. A., Ahmad, A. and Arshad, M. 2012. Comparative studies on seed cotton yield in relation to planting dates under diverse agroenvironment of Punjab. Pakistan Journal Agriculture Science, 64(1): 5963.

Salakinkop, S. R. 2011. Enhancing the productivity of irrigated $B t$ cotton (Gossypium hirsutum) by transplanting and planting geometry. Indian Journal of Agricultural Sciences, 81(2): 150153.

Zaheer, A. D., Shamshuddin, T., Qammaruddin and Chand, F. O. 2014. Impact of planting dates and picking stages on yield and seed maturity of cotton (Gossypium hirsutum L.) varieties. Sarhad Journal of Agriculture, 30(4): 404-410.

\section{How to cite this article:}

Pyati, P.S., B.M. Chittapur, A.S. Halepyati, U.K. Shanwad and Bhat, S.N. 2019. Effect of Site Specific Nutrient Management, Crop Establishment Methods and Date of Sowing on Growth, Yield and Economics of Bt Cotton. Int.J.Curr.Microbiol.App.Sci. 8(07): 896-902. doi: https://doi.org/10.20546/ijcmas.2019.807.107 